\title{
Treatment of Extraoral Sinus Tract with Endodontic Intervention: A Case Report
}

\author{
Ektraoral Fistülün Endodontik Müdahale İle Tedavisi: Olgu Sunumu \\ Güneş KARAKAYA (D), Emre İRİBOZ (D), Hesna SAZAK ÖVEÇOĞLU (10
}

Öz

Odontejenik fistüller çoğunlukla pulpa enflamasyonuna bağlı gelişen tedavisi için genellikle kanal tedavisi nadiren de cerrahi işlem gereken patolojik oluşumlardır. Pek çoğu intraoral olarak oluşmasına rağmen bazen ekstraoral olarak da gözlemlenebilmektedir. Ekstraoral fistül, ağız boşluğu ve cilt arasında patolojik bir yoldur. Hastaların genellikle dental semptomları olamaması sebebiyle pek çok diğer cilt lezyonu ile karışabilmekte ve etkisiz tedaviler uygulanabilmektedir. $\mathrm{Bu}$ sebeple bu vakaların ayırıcı tanısının yapılması oldukça önemlidir. Bu vaka sunumu, alt çene kesici dişlerden oluştuğu tespit edilen ve çene ucu bölgesinden drene ekstraoral fisstül vakasının kök kanal tedavisi uygulamasının ardından 3 aylık takibini içermektedir.

Anahtar Kelimeler: Deri lezyonları, ekstraoral fistül, kök kanal tedavisi, odontojenik fistül, periapikal lezyon

Güneş KARAKAYA(函)

Marmara Üniversitesi, Diş Hekimliği Fakültesi, Endodonti Anabilim Dalı

e-mail:karakayagunes@gmail.com

Assc. Prof. Dr. Emre İRIBOZ, Prof. Dr. Hesna Sazak ÖVEÇOĞLU

Marmara Üniversitesi, Diş Hekimliği Fakültesi, Endodonti Anabilim Dalı

Submitted / Gönderilme: 18.09.2019

Accepted / Kabul:30.06.2020

\begin{abstract}
Odontogenic sinus tracts, mostly caused by pulp inflammation are pathologic formations which usually require root canal treatment and rarely surgical procedures. Although most of them occur intraorally, they may also occur extraorally. An extraoral sinus tract is a pathologic pathway between the oral cavity and the skin which can be confused with many other skin lesions and ineffective treatments may be applied because the patients usually do not have dental symptoms. Therefore, the differential diagnosis of these cases is very important. This case report describes the treatment and 3 month follow-up of an extraoral sinus tract which derives from lower incisors.

Keywords: Extraoral sinus tract, odontogenic fistula, periapical lesion, root canal treatment, skin lessions
\end{abstract}

\section{Introduction}

Odontogenic sinus tracts are pathological occurrences due to pulp necrosis that requires conventional or rarely surgical endodontic treatment to heal. They are mainly detected intraorally and in uncommon cases, they may exist extraoral, depending on the root location, bone thickness, muscle inserts, and localization of the perforation in the cortical bone.[1-5] Discharge of exudate which flows through tissues along the least resistant pathways is commonly associated with the periapical radiolucent lesion.[6]

Even if extraoral sinus tracts of dental origin are not rare, misdiagnosis and inappropriate treatment frequently occur. [7] Patients may not associate extraoral sinus tracts with teeth and often may not have symptoms of endodontic origin, so they frequently apply to the general practitioner rather than the dentist.[8, 9] The physician should keep in mind that the lesions seen in the face area may have an odontogenic origin and differential diagnosis should be made. Extraoral sinus tracts can often be confused with skin lesions, pyogenic granuloma, traumatic injury, carcinoma, osteomyelitis, congenital fistula, tuberculosis, and actinomycosis.[10-15] 
It is essential that interaction occurs between physicians and dentists to avoid exposing patients to insufficient treatment procedures.[5] It has been reported that half of the patients with extraoral fistula were exposed to unnecessary surgical interventions and long-term antibiotic treatments before the correct diagnosis.[16] Not identifying the endodontic origin commonly leads to unfavorable treatment which will not be therapeutic, for example, skin biopsies may lead to unnecessary scarring.[17, 18] Once the correct diagnosis is made, definitive treatment, through either tooth extraction or root canal therapy to eliminate the source of infection, is simple and effective.[19]

In this case report, the diagnosis and treatment of an odontogenic extraoral sinus tract are described.

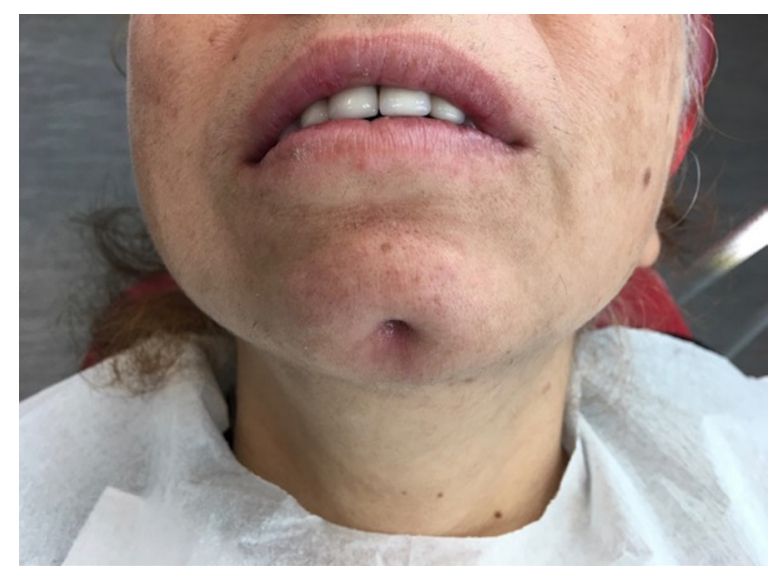

Fig 1: First Session

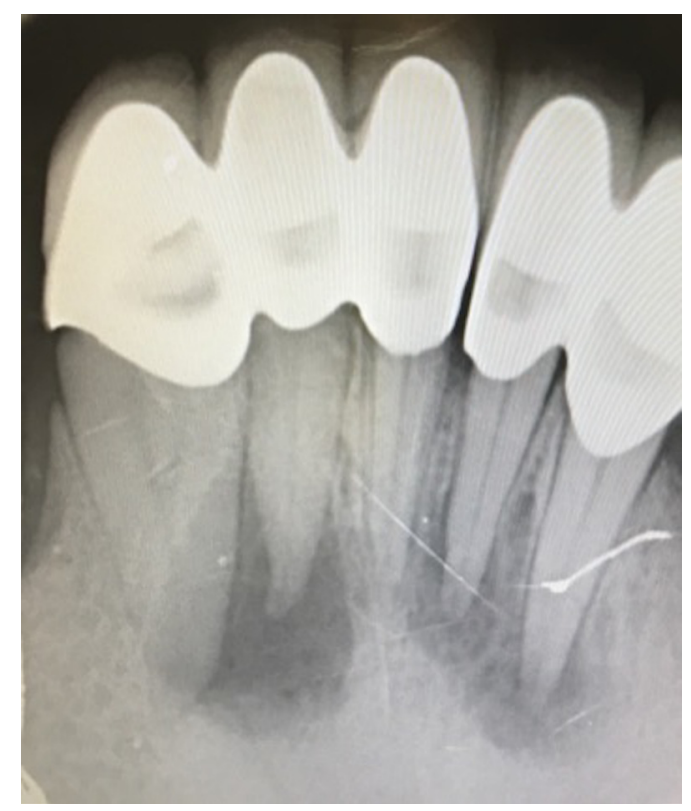

Fig 2: Initial Radiograph

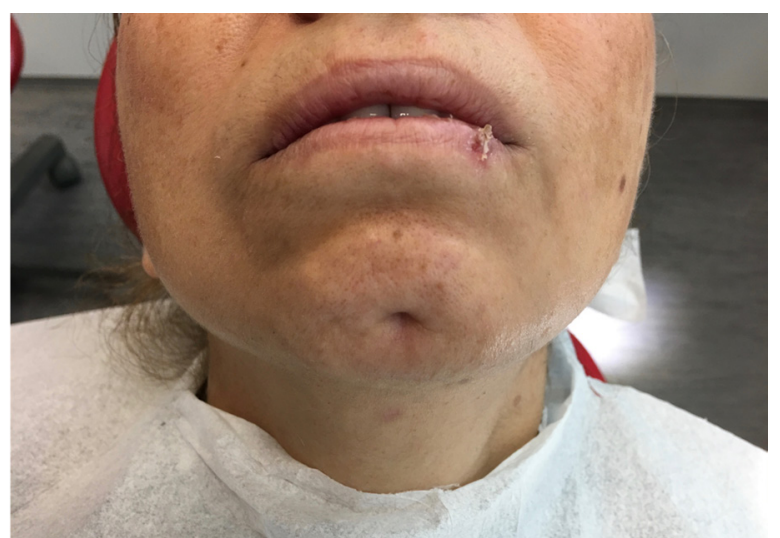

Fig 3: Post-op 1 week

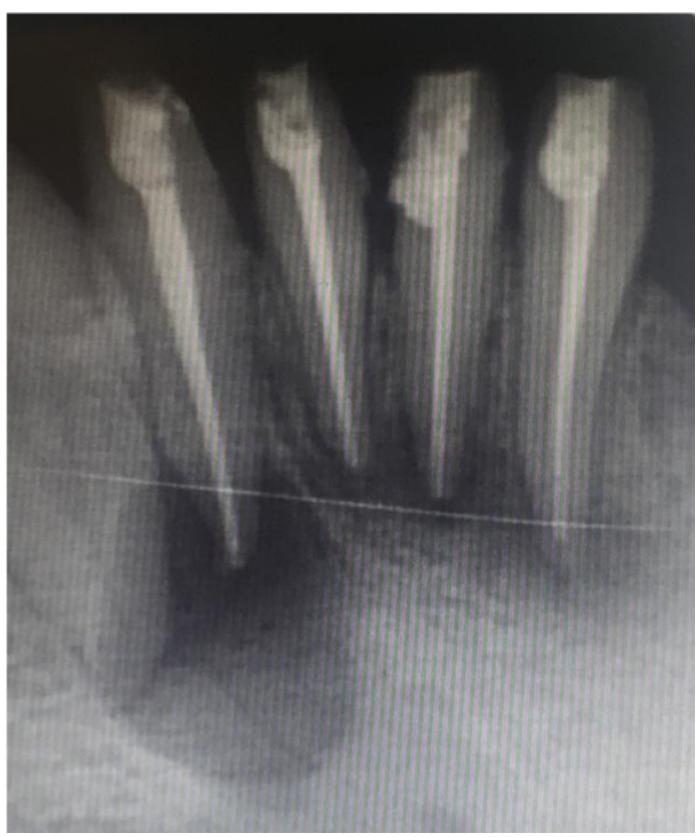

Fig 4: Post-op 1 month radiograph

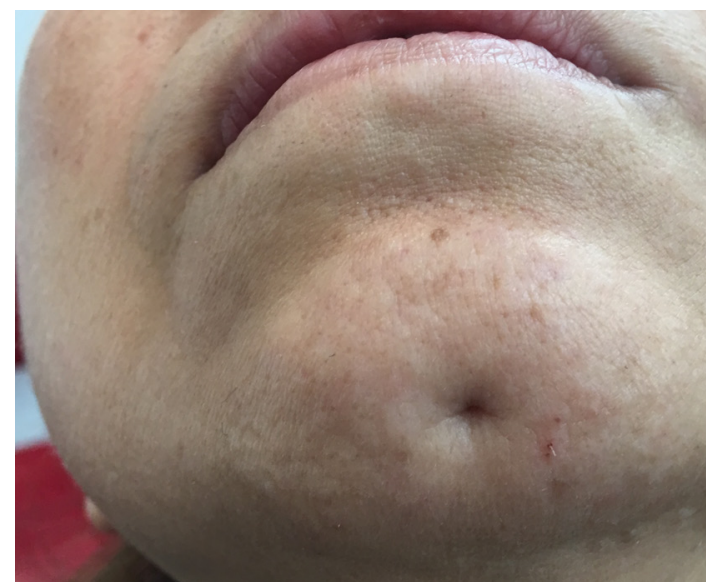

Fig 5: Post-op 1 month 


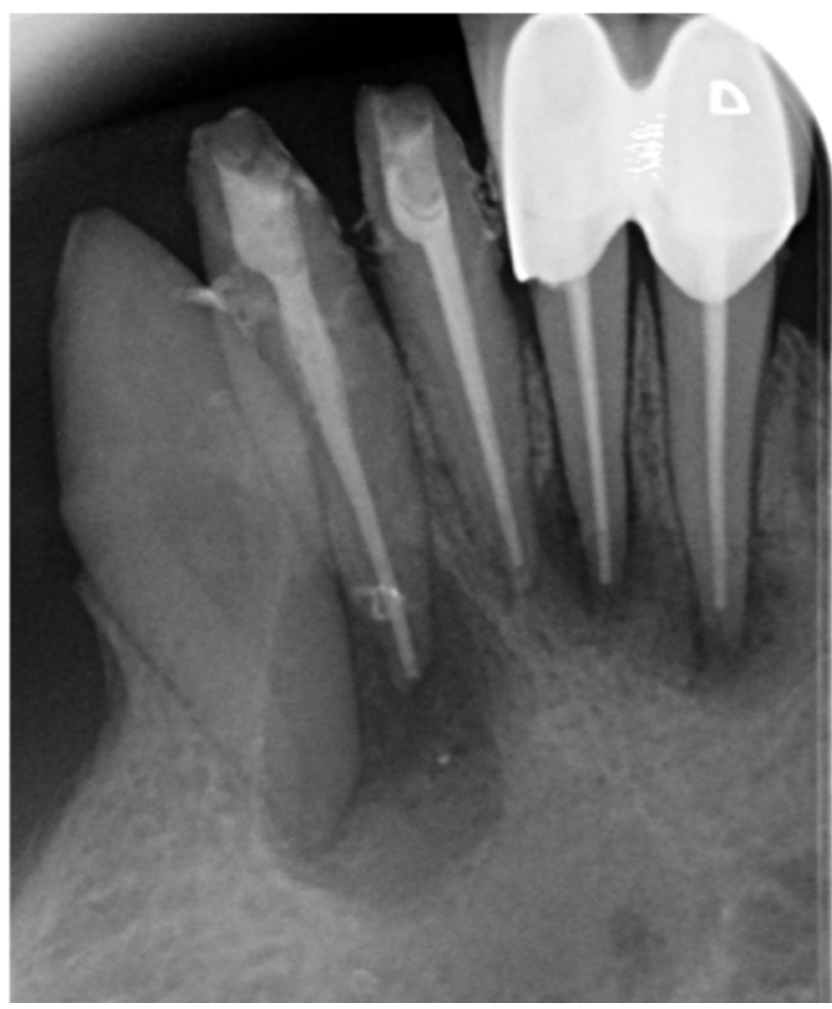

Fig 6: Post-op 2 month radiograph

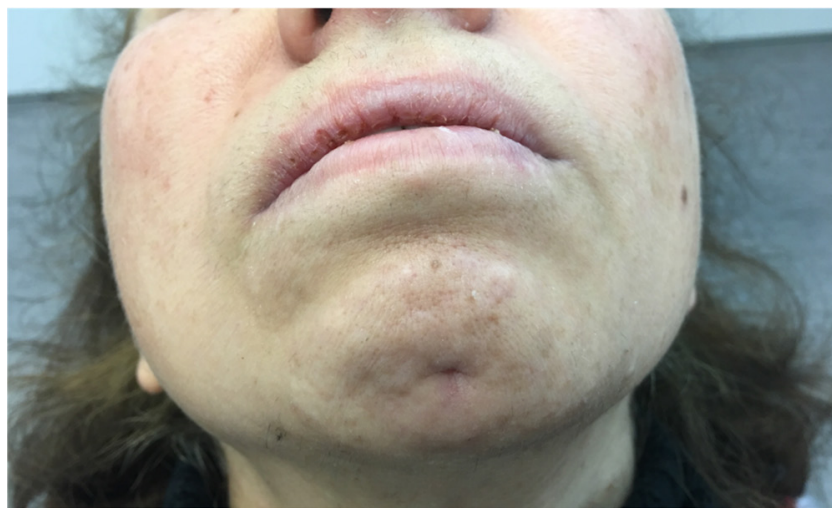

Fig 7: Post-op 3 month

\section{Case Report}

A 50-year-old female patient with a noncontributing medical history was referred to our clinic with extraoral swelling and pain associated with the mandibular incisors. Extraoral examination showed an extraoral sinus tract 3 $\mathrm{mm}$ in width at the submental region which confirmed the diagnosis of the chronic apical abscess. Dental anamnesis showed that the patient had the sinus tract for 1 month
Clarithromycin was prescribed for the patient in emergency services by a physician before applying to our clinic. In the radiologic examination, there was a well defined periapical radiolucent region associated with mandibular incisors. Teeth were slightly sensitive to percussion and palpation. The involved incisors did not respond to electrical pulp tests. The diagnosis was established as chronic periapical abscess resulting from pulp necrosis due to prosthetic procedures. Lower right canine vitality test was positive so it was decided not do perform root canal treatment for this teeth After placing a rubber-dam, root canal treatment was initiated with gaining a proper access cavity and chemomechanical preparation of the root canals. Working length was measured with an electronic apex locator and confirmed with a periapical radiograph, in the root canals of all teeth. The root canals were prepared using the Protaper Next NiTi instrumentation system and irrigated with 5.25\% $\mathrm{NaOCl}$ and \%17 EDTA solutions. Excessive exudate in the root canals and also mild serous exudate from the sinus tract were detected during preparation. Calcium hydroxide paste was used as intracanal medication. Visits and calcium hydroxide replacements were replied until the drainage ceased. When the teeth became asymptomatic and there was no exudate, root canals were obturated with gutta-percha and $\mathrm{AH}$ Plus using the lateral condensation technique. After 1 week the sinus tract area started to shrink and in the following 3 months, it was even smaller. There were no symptoms observed at the control sessions except for a minimal palpation sensitivity. Follow-up was considered to be more appropriate than root canal retreatment because more time was required for complete recovery of the case.

\section{Discussion}

Intraoral or extraoral sinus tract drainage depends on the path that is less resistant to the progression of the exudate produced, the proximity of the apex to the external bone cortex, the length, and slope of the root involved, bacterial virulence, the patient's defense mechanism, low resistance of the tissues in the facial region and the relationship between the muscle attachment and the infected tooth and on the morphology of the affected jaw. If the apical section of the teeth is above the maxillary muscle connections or below the mandibular muscle connections, the infection may spread to the extraoral region.[20-25]

Gupta \& Hasselgren reported the rate of sinus tract formation in teeth with periapical inflammation as $18 \%$. 
[2] Mortensen et al. also investigated teeth with periapical lesions; $9.0 \%$ teeth had sinus tracts. Teeth with periapical lesions smaller than $5 \mathrm{~mm}$ had sinus tracts in $5 \%$ of cases, whereas teeth with periapical lesions greater than or equal to $5 \mathrm{~mm}$ had sinus tracts in 19\%.[26] Extraoral sinus tracts are occasionally seen.[27] Almost $80 \%$ of reported cases are associated with mandibular teeth and $20 \%$ with maxillary teeth.[28] The most frequent regions of involvement are the chin and submental regions.[24, 28] It should be considered that the lesions seen in the face area may have an endodontic origin and the differential diagnosis must be made.[14] After careful clinical and radiographic examination, teeth associated with the lesion can be identified. Thus, appropriate treatment is performed and unnecessary drug use and surgical interventions are avoided.[29] The clinical and radiological examination should be performed carefully in order to make the correct diagnosis. Vitalometric examination should be performed. If necessary, the guttapercha or lacrimal probe can be placed outside the mouth to detect the source.[6, 16, 30-32] An essential diagnostic method is the determination of the nature of fluid draining (if any) from the cutaneous sinus tract, an attempt should be made during palpation to milk the sinus tract. Any discharge obtained should be examined to determine its nature (saliva, pus, or cystic fluid).[10, 33]

Treatment choice is nonsurgical endodontic therapy if the tooth is restorable. Extraction is indicated for nonrestorable teeth.[24, 28, 34] After 5 to 14 days following root canal treatment, the sinus tract is expected to close spontaneously.[8, 30, 35] This area usually heals with a slight pit and hyperpigmentation, decreasing over time.[35] Nonsurgical endodontic therapy, sometimes complemented by surgery, for extraoral sinus tracts of endodontic origin. [6] Hyperbaric oxygen therapy may also be used in cases that are massive and require surgery.[36, 37] The complete recovery of the extraoral sinus tracts reported as 5 months to 1 year in the literature.[29, 37-39] Therefore, it was decided to follow this case to fully recover the extraoral sinus tract.

Differential diagnosis should be made considering that skin lesions seen in the face and neck area may originate from endodontic infections. The accurate diagnosis based on the communication between the physician and the dentist ensures that the treatment should be made as soon as possible, protecting the patient from unnecessary waste of time, antibiotic use, and further infection.

\section{References}

1. Cohenca N, Karni S, Rotstein I. Extraoral sinus tract misdiagnosed as an endodontic lesion. J Endod 2003;29:841843.

2. Gupta R, Hasselgren G. Prevalence of odontogenic sinus tracts in patients referred for endodontic therapy. J Endod 2003;29:798-800.

3. M Assery SAS. Cutaneous facial sinus tract of dental origin: a clinical case report. Saudi Dent J 2011;13:37-39.

4. Nakamura Y, Hirayama K, Hossain M, Matsumoto K. A case of an odontogenic cutaneous sinus tract. Int Endod J 1999;32:328-331.

5. Sotiropoulos GG, Farmakis ET. Diagnosis and conservative treatment of extraoral submental sinus tract of endodontic origin: a case report. J Clin Diagn Res 2014;8:10-11.

6. Pasternak-Júnior B, Teixeira C, Silva-Sousa Y, Sousa-Neto M. Diagnosis and treatment of odontogenic cutaneous sinus tracts of endodontic origin: three case studies. Int Endod J 2009;42:271-276.

7. Lee E-Y, Kang J-Y, Kim K-W, Choi KH, Yoon TY, Lee JY. Clinical characteristics of odontogenic cutaneous fistulas. Ann Dermatol 2016;28:417-421.

8. Johnson BR, Remeikis NA, VAN CURA JE. Diagnosis and treatment of cutaneous facial sinus tracts of dental origin. JADA 1999;130:832-836.

9. Atan Ö, Küçükçelebi A, Özman Ç. Iatrogenic Cutaneous Sinus Tract of Dental Origin: Case Report. J Pediatr Res 2015;2:96-98.

10. Cohen PR, Eliezri YD. Cutaneous odontogenic sinus simulating a basal cell carcinoma: case report and literature review. Plast Reconstr Surg 1990;86:123-127.

11. Fatouris PN. A cautionary tale. Case report. Aust Dent J 2000;45:53-54.

12. Foster KH, Primack PD, Kulid JC. Odontogenic cutaneous sinus tract. J Endod 1992;18:304-306.

13. Held J, Yunakov M, Barber R, Grossman M. Cutaneous sinus of dental origin: a diagnosis requiring clinical and radiologic correlation. Cutis 1989;43:22-24.

14. Wilson S, Ward D, Burns A. Dental infections masquerading as skin lesions. Br J Plast Surg 2001;54:358-360.

15. Yasui H, Yamaguchi M, Ichimiya M, Yoshikawa $Y$, Hamamoto Y, Muto M. A case of cutaneous odontogenic sinus. J Dermatol 2005;32:852-855.

16. Cantatore JL, Klein PA, Lieblich LM. Cutaneous dental sinus tract, a common misdiagnosis: a case report and review of the literature. Cutis 2002;70:264-267.

17. Curvers F, De Haes P, Lambrechts P. Non-surgical endodontic therapy as treatment of choice for a misdiagnosed recurring extraoral sinus tract. Eur Endod J 2017;2:13.

18. Mittal N, Gupta P. Management of extra oral sinus cases: a clinical dilemma. J Endod 2004;30:541-547.

19. Dinçol M, Yılmaz B, Ersev H, Gündüz VM, Arslanoğlu B, Yalçın T, et al. Treatment of extraoral cutaneous sinus tracts with non-surgical endodontic intervention: report of six cases. J Istanb Univ Fac Dent 2015;49:35-40. 
20. Javid B, Barkhordar R. Chronic extraoral fistulae of dental origin. Compendium 1989;10(8): 11-14.

21. Kayahan MB, Kaptan F, Altundal H, Bayirli G. The management of an odontogenic cutaneous sinus tract: a case report. Ohdmbsc 2003;2:60-63.

22. Brown RS, Jones R, Feimster T, Sam FE. Cutaneous sinus tracts (or emerging sinus tracts) of odontogenic origin: a report of 3 cases. Clin Cosmet Investig Dent 2010;2:63.

23. Leonardo RT, Leal JM, Leonardo MR. Urgências em endodontia: pulpopatias, periapicopatias. In: Leonardo MR, Leal JM (eds). Endodontia: tratamento de canais radiculares. Sao Paulo: Panamericana 1998:885-902.

24. Cioffi G, Terezhalmy GT, Parlette H. Cutaneous draining sinus tract: an odontogenic etiology. J Am Acad Dermatol 1986;14:94-100.

25. Stoll HL, Solomon HA. Cutaneous sinuses of dental origin. JAMA 1963;184:120-124.

26. Mortensen H, Winther J, Birn H. Periapical granulomas and cysts: An investigation of 1,600 cases. Eur J Oral Sci 1970;78:241-250.

27. Chan C, Jeng J, Chang S, Chen C, Lin C, Lin C. Cutaneous sinus tracts of dental origin: clinical review of 37 cases. $\mathrm{J}$ Formos Med Assoc 1998;97:633-637.

28. Hodges TP, Cohen DA, Deck D. Odontogenic sinus tracts. Am Fam Physician 1989;40:113-116.

29. Işık V, Ersev H. Extraoral fistula: A case report. Yeditepe J Dent 2018;14:137-140.

30. 30. Al-Kandari AM, Al-Quoud OA, Ben-Naji A, Gnanasekhar JD. Cutaneous sinus tracts of dental origin to the chin and cheek. Quintessence Int 1993;24.
31. Soares JA, De Carvalho FB, Pappen FG, Araújo GS, De Pontes Lima RK, Rodrigues VMT, et al. Conservative treatment of patients with periapical lesions associated with extraoral sinus tracts. Aust Dent J 2007;33:131-135.

32. Witherow H, Washan P, Blenkinsopp P. Midline odontogenic infections: a continuing diagnostic problem. Br J Plast Surg 2003;56:173-175.

33. 33. Wood G. Pitts, fistulas, and draining lesions In: Cherrick HM (eds). Differential diagnosis of oral lesions. St. Louis: Mosby Co 1985:199 -201.

34. Tidwell E, Jenkins J, Ellis C, Hutson B, Cederberg R. Cutaneous odontogenic sinus tract to the chin: a case report. Int Endod J 1997;30:352-355.

35. Spear KL, Sheridan PJ, Perry HO. Sinus tracts to the chin and jaw of dental origin. J Am Acad Dermatol 1983;8:486-492.

36. Wilcox JW, Kolodny SC. Acceleration of healing of maxillary and mandibular osteotomies by use of hyperbaric oxygen: A preliminary report. Oral Surg Oral Med Oral Pathol 1976;41:423-429.

37. Zerener T, Bayar G, Gulses A, Simsek K, Aydintug Y. Massive cutaneous fistula secondary to an odontogenic submandibular abcess in an immunocompromised patient: a case report. Cumhuriyet Dent J 2014;1:11-15.

38. Zan R, Kanmaz F, Akpınar KE, Hubbezoğlu I. Treatment of an extraoral cutaneous sinus tract with endodontic intervention: a case report. Turk Endod J 2016;1:39-42.

39. Kumar KS, Subbiya A, Vivekanandhan P, Prakash V, Tamilselvi R. Management of an endodontic infection with an extra oral sinus tract in a single visit: a case report. Journal of clinical and diagnostic research. J Clin Diagn Res 2013;7:1247. 